\title{
Research on Current Status and Countermeasures of "Double-position Teachers" Cultivation in Business English Major in Applied Technology Colleges in “Internet+" Age
}

\author{
Yang Meifang \\ Institute of Technology. East China Jiaotong University, Nanchang Jiangxi, 330100, China
}

Keywords: Internet+; business English; professional teachers; double-position

\begin{abstract}
Talents in business English is the bridge for the cooperation between domestic and foreign enterprises, teachers of business English is the cultivator of relevant talents, therefore, the teaching proficiency of teachers in business English has attracted much attention. "Double-position teachers" is the new requirement for business English teachers in the new trend and plays an obviously important role in the cultivation of talents in business English.
\end{abstract}

The medium and long-term development plan of national education talents formulated recently points out that the construction of teaching staff shall take "double-position teachers" as key content, comprehensively improve professional level and occupational quality of teachers, take joint training between colleges and enterprises, improve the proportion of "double-position teachers" with a period of time to cultivate more qualified talents for China's opening to the outside world. Therefore, the cultivation of “double-position teachers” in business English major is essential.

\section{Current Status and Main Problems in the Development of Business English Teaching Staff}

\subsection{The development of business English major education}

The widely used business English develops in the actual application step by step, and requires students to have solid English basic knowledge and ability to organize business activities and interpersonal communication. In 2007, University of International Business and Economics obtained the approval of Ministry of Education and was the first to set business English major, many colleges and universities also set business English major later, and almost 700 colleges and universities have set business English major at present, which provides abundant reserve of talents and widen employment channels for students from English major.

\subsection{Main problems in teaching staff of business English major}

The current teaching competence of teachers in the emerging business English is uneven, lacking professional knowledge and practical ability. It is a branch and extension of English major with language knowledge as the foundation, and what is more important is relevant business knowledge, including international trade, economic management, marketing, law, finance and etc. Therefore, business English is a social science with strong inter-disciplines, including language knowledge, commercial knowledge, social skills, cultural knowledge and so on, and teachers in the major shall have rich experience and theory of business practice, and outstanding English application proficiency. Business English, as an emerging major, lacks professional teachers because most teachers in the major now are from English major who have little understanding of business knowledge, which influences badly the cultivation of talents in business English.

The content of business English is more close to business practice, and students have wide scope for selection of jobs after graduation, such as international commercial vouching clerk, foreign trade merchandiser, international freight forwarder, inspection staff, customs declarer and etc. Based on the requirement of actual position, students shall be proficient in existing regulations on national management of import and export commodities, relevant law and regulations and policies on foreign customs duties, and basic procedures of import and export trade, can understand and rapidly 
deal with procedures and contracts involved in import and export trade, and master methods and skills of foreign trade documents production, which are all necessary skills to be grasped in business work. Therefore, business English is not only about the language learning, also involving business, law, import and export and so on with strong professional practicalness, which requires certain commercial practical ability for business English teachers. At present, most teachers in business English have only accepted education on English in general colleges and universities, traditional teaching mode lacks the cultivation of practical ability, and there is a shortage of education on teachers. In addition, the curriculum arrangement is unreasonable, theory courses are obviously more than practice course, which results in the insufficient understanding of commercial environment and practical experience for students who have high theory knowledge level, which affects the development of students in society. Meanwhile, due to constraints of various elements, many students are reluctant to work in import and export enterprises of foreign trade, preferring the teaching work in schools, which results in the fact that relevant teachers only teach content in teaching materials, lacking practical experience and deep understanding of society, and students trained have poor social practical ability and cannot satisfy requirements of opening to the outside world ${ }^{[2]}$.

In addition, different from English major, business English teaching lacks the simulation of real scenes and real business activities, which are the most required knowledge for students, however, the work in this aspect in many colleges and universities is not in place and there are many problems in the teaching.

\section{Basic Connotation and Necessary Quality of Double-position Teachers}

\subsection{Basic connotation of double-position teachers}

There is not clear definition on "double-position teachers” from the country. Relevant scholars have different interpretations, first of all, double-position teachers shall have double certificates, which include teacher certification required for a teacher and necessary professional qualification certifications. At the same time, teachers need to have double qualities, including solid theory knowledge and rich practical experience. Some scholars also point out that double-position teachers are required to have higher professional ethics, corresponding professional theory and practical knowledge, certain economic common sense and social skills, innovative spirit and higher management level. In short, double-position teacher is the new requirement for the comprehensive quality of teachers and plays a significant role in the cultivation of national talents ${ }^{[3]}$.

\subsection{Necessary quality of double-position teachers}

Teachers in business English major with comprehensive quality are double-position teachers meeting the requirement of times, who shall have strong practical ability and relevant professional qualification certifications in addition to teacher certification, including foreign trade customs declarer, vouching clerk and etc. Besides, they need double qualities, including knowledge skills and practical experience of foreign trade import and export in addition to higher English proficiency so as to provide guidance and teaching for students. In other words, teachers in business English are required to teach knowledge accurately in class and be equipped with capabilities of various work in trade enterprises after class ${ }^{[4]}$.

\section{Approaches for the Construction of Double-position Business English Teaching Staff}

\subsection{To strengthen the training of business English teaching staff}

At present, in order to adapt to the new trend, strengthen practical ability of students, and widen employment channels, many colleges and universities set interpreting, business English major and so on in addition to originally existing English major, and many English major teachers gradually begin to transform to the teaching of business English, alleviating the saturation of English major teachers. For the teacher resources transforming to other majors halfway, to strengthen the training 
of professional skills is an important task which can be conducted from various aspects.

First of all, cooperation with domestic well-known colleges and universities can be conducted to select some teachers for regular training communication and learning of business English major to enhance professional capability through more professional and systematic learning in well-known colleges and universities, and communication with teachers, strengthen business English theory knowledge, improve the understanding of business English major, update teaching knowledge system and structure of themselves, and transform business English teaching to be more suitable for the development of students in the future.

Secondly, social practical activities of teachers shall be strengthened to increase opportunities of social practice for teachers. Colleges and universities can cooperate together to select parts of teachers to work in all kinds of foreign companies through post practice or temporary post, including business assistant, export sales staff, customs declarer, foreign trade agent, merchandiser, vouching clerk and etc. Teachers can learn useful knowledge for students, improve business knowledge structure, enrich practice experience, at the same time, and understand operation of enterprise and talent requirement to adjust curriculum content according to social practice and lay a solid foundation for students to enter the society ${ }^{[5]}$.

Regularly select relevant teachers to participate in business English seminars organized by the Business English Research Association, the Association of International Trade, etc., and strengthen communication with other professional teachers of other institutions. Seminars on business English course setting, business English teaching, etc. are conducted to strengthen the teaching level of business English major teachers and improve teaching quality.

Colleges and universities need to create more practical opportunities for students to participate competition activities held by institutions, such as POCIB training and competition held by China Association of International Trade and Desunsoft, series of competitions of business English once held by Heilongjiang Society for Business English Studies, National Business English Practice Contest held by School of English for International Business, Guangdong University of Foreign Studies, and the like, which are beneficial for students to enhance the capability to combine theory knowledge with practice, improve comprehensive practical ability, understand procedures of foreign trade, and for teachers to strengthen teaching level and coaching ability ${ }^{[6]}$.

Institutions can regularly invite personnel in business English and foreign trade industry to give lectures and guidance, and in this way, teachers can understand the specific requirements of the society for business English personnel in time, grasp the latest industry information, and adjust the teaching content in time so that students can learn better to adapt to changes in the social situation.

\subsection{To focus on the talent introduction of teachers}

At present, due to the constraints of objective conditions, there is a shortage of teacher talents in business English major in many colleges and universities, which seriously affects the teaching of business English major. Therefore, the cooperation with excellent colleges and universities shall be strengthened to employ more double-position teachers with rich practical experience, solid language knowledge, understanding of operation procedures of import and export enterprises of foreign trade and latest information in all kinds of industries, so as to comprehensively improve the teaching of business English. The introduction of excellent teachers can promote the general level of teaching staff, accelerate the construction of double-position teachers, encourage teachers to teach knowledge more close to the reality, and fully attract the learning interests of students to learn skills required in actual work in the future, so as to lay a foundation for them to enter the society and enterprises. At the same time, teachers also can create more opportunities of internship with their own resources, and encourage students to visit and study in enterprises related to business English major, so as to discover and solve problems may occurring in future work. In addition, strict assessment shall be performed on outside business English teachers to form reasonable teaching methods to ensure teaching quality and to comprehensively improve the learning of students with the combination of teachers inside and outside colleges and universities ${ }^{[7]}$. 


\subsection{To strengthen the school-enterprise cooperation}

The construction of a double-position teaching staff in business English with high quality to meet the requirement of the society requires the close cooperation and co-construction of colleges and universities and enterprises. If it is completed only by colleges and universities from one side, it will be seriously separated from social practice and bring certain difficulties for the employment of students, thus it is necessary to cooperate with related enterprises. The co-construction of colleges and universities and enterprises can be conducted from various ways.

At first, it is essential to fully enhance the emphasis on business English teaching, establish specific department for building the business English teaching staff, conduct comprehensive and in-depth investigation and study in the society, understand the needs of import and export industrial professionals for enterprises, the requirements of occupational ability, through the actual investigation and research, obtain the most direct information on the needs of employers, and constantly improve the teaching program, improve the overall cultivation of double-position business English teachers, and improve the level of business English talent cultivation.

Secondly, specific service stations for business English teachers shall be set up in colleges and universities, which is the best platform to improve teachers' professional competence and the ability to adapt to and serve the society, and enhance teaching research and scientific research of teachers. Service stations can integrate all kinds of latest resources in business English and share information to help teachers to improve their own work level, the teaching more close to the reality and students into the society more successfully.

Meanwhile, service stations for teachers can better provide service for enterprises. In the co-construction of higher institutions and enterprises, in general, enterprises invest a large amount of capacity transformation, however, the actual results of talent cultivation is not obvious, the requirement of talents is also not satisfied. Whereas, service stations for teachers effectively solve the problem, practically improve the importance of enterprises in the construction of business English teaching staff to be involved in the talent cultivation of colleges and universities. Besides, the establishment of service stations for business English teachers also create more opportunities of participating actual work in enterprises, enterprises conduct comprehensive evaluation based on work performance and achievement and actual work ability of relevant business English teachers in enterprise service stations to make objective assessment on their work ability and occupational quality. The ways of participation in enterprises can be determined by arrangement of colleges and universities, including winter and summer holiday, weekends, off-job training and so on.

\subsection{To perfect the cultivation mechanism of teachers and construct certification system for the participation of teachers in social practice}

Business English is a discipline with strong applicability, therefore, it is necessary for teachers to have actual work experience, understand the requirement of talents for related enterprises and specific demands of occupational skills, and conduct the teaching combining the reality. Colleges and universities need to perform assessment and certification on the practical ability of teachers, and teachers with insufficient practical ability are required to study in service stations for teachers, so as to improve professional quality of teaching staff and accelerate the construction of double-position teachers in business English.

\section{Conclusion}

With the accelerating pace of reform and opening-up, the requirement of talents in business English is increasing continuously. The level of teaching staff of business English major in colleges and universities needs to be strengthened and the cultivation of double-position teachers is urgent. In the process, it is necessary for colleges and universities to fully consider actual situation, create opportunities of social practice through various channels, strengthen the cooperation and co-construction of related enterprises, and comprehensively promote the effective teaching of business English so as to cultivate more talents in business English for China's economic 
development.

\section{References}

[1] Zhu Yanning. Exploration on Cultivation Channels of Double-position Teachers in Business English Major [J]. Journal of Mudanjiang College of Education, 2014(03):39+56.

[2] Sun Rui. Study on Strategies of Incubation of Double-position Teachers in Business English Based on Innovation and Entrepreneurship Education [J]. English Teachers, 2017, 17 (02):23-25+29.

[3] Yu Hongying. Study on the Construction of Double-position Teachers in Business English in Higher Vocational Colleges [J]. Education and Vocation, 2015(18):68-70.

[4] Wang Limin, Yuan Jing, Chen haijuan. Study on the Construction of Double-position Teachers in Business English [J]. Heilongjiang Researches on Higher Education, 2014(03):76-78.

[5] Nie Jide. Exploration on Approaches for the Construction of Double-position Teachers in Business English Major [J]. Modern Communication, 2012(10):180+179.

[6] Yang Lu. Discussion on Hierarchy Construction of Double-position Teachers in Newly-established Applied Undergraduate Colleges and Universities-Taking Business English Major as an Example [J]. Journal of Chongqing University of Education, 2016, 29 (05):113-116.

[7] Wu Huihui. Construction of Professional Development System on Cultivating "Double-qualified" Teachers for Vocational Institutions Based on College-enterprise Cooperation-Taking Business English Major as an Example [J]. Journal of Heihe University, 2017, 8 (12):120-121. 